\title{
Conference Paper Oncothermia with Chemotherapy in the Patients with Small-Cell Lung Cancer
}

\author{
Doo Yun Lee, ${ }^{1}$ Seok Jin Haam, ${ }^{1}$ Tae Hoon Kim, ${ }^{2}$ Jae Yun Lim, \\ Eun Jung Kim, ${ }^{1}$ and Na Young Kim ${ }^{1}$ \\ ${ }^{1}$ Department of Thoracic \& Cardio-Vascular Surgery, Gangnam Severance Hospital, College of Medicine, Yonsei University, \\ Seoul 120-752, Republic of Korea \\ ${ }^{2}$ Department of Diagnostic Radiology, Gangnam Severance Hospital, College of Medicine, Yonsei University, \\ Seoul 120-752, Republic of Korea \\ ${ }^{3}$ Department of Medical Oncology, Gangnam Severance Hospital, College of Medicine, Yonsei University, \\ Seoul 120-752, Republic of Korea
}

Correspondence should be addressed to Doo Yun Lee; dylee@yuhs.ac

Received 18 January 2013; Accepted 3 April 2013

Academic Editors: G. Baronzio, M. Jackson, and A. Szasz

This Conference Paper is based on a presentation given by Doo Yun Lee at "Conference of the International Clinical Hyperthermia Society 2012” held from 12 October 2012 to 14 October 2012 in Budapest, Hungary.

Copyright (C) 2013 Doo Yun Lee et al. This is an open access article distributed under the Creative Commons Attribution License, which permits unrestricted use, distribution, and reproduction in any medium, provided the original work is properly cited.

Small-cell lung cancer (SCLC) is one of the most aggressive and lethal forms of lung cancers. Chemotherapy and radiotherapy would be standard modality for SCLC with median survival being less than 4 months only. Complementary treatment to chemotherapy is desired. Oncothermia will be one of the candidates to this addition. We have made a study of 31 SCLC patients from April 2006 to March 2012. 23 cases were treated with combined chemotherapy and oncothermia, and 8 cases were treated with chemotherapy alone. Three patients from 14 patients (14/31) died in the study period; there were equal numbers in the two arms, including one long survival case of 28 months and one of 26 months, in the combination and chemo-group, respectively .16 patients (16/31) are alive: 4 patients with chemotherapy only, including one long survival case of 28.7 months, and 11 cases with combined therapy including three long survival cases of more than 3 years. We conclude that the combined use of chemotherapy and oncothermia has significantly enhanced the survival rate in comparison with the use of chemotherapy alone (log-rank test: $P$ value $<0.02)$.

\section{Introduction and Background}

Lung cancer is one of the most common causes of cancerrelated deaths in both men and women worldwide. Its incidence as well as mortality rates is high, and the prognosis is usually very poor [1]. Its age-standardized incidence and mortality rates in 2006 were estimated to be 75.3 and 64.8/100 000/year, respectively, in men and 18.3 and $15.1 / 100000 /$ year in women in Europe, where the small-cell lung cancer (SCLC) accounts for $15 \%-18 \%$ of all cases [2]. The small-cell lung cancer has a fast growth-rate, disseminated quickly around the mediastinal lymph nodes, and forms distant metastases in late diagnosis, and then the median survival is only 2-4 months; the overall prognosis is very poor $[3,4]$.

Surgical treatment is not possible in almost all SCLC cases; it could be performed in very limited stage of the disease (i.e. T1,N0) only [2]; consequently the main treatments are chemo- and radiotherapy. The overall 2-year survival rate is less than 20\%; and 5-year survival rate is almost devoid. In $50 \%$ of relapse SCLC cases chemotherapy reached complete remission (CR). In these the bulky primary tumors were completely destroyed but most intrathoracic recurrence was difficult to discover. In cases when radiotherapy was added, [5], recurrence rate has been reduced in 30-60\% of the cases, however radiation pneumonitis, esophagitis was observed, 
but the overall survival rate was significantly improved [6]. Moreover, most of the extensive advanced SCLC may develop anticancer drug resistance for chemotherapy. The overall survival rate is very poor, median survival is $7-10$ months, 2 -year survival rates is the less than $5 \%$, so the prognosis is poor. In a study of University of Toronto [7] including 119 SCLC patients, the median survival was 111 weeks and 5-year survival rate was $39 \%$ of 119 SCLC patients. The stage-specific survival stage I was $51 \%$, 28\% for stage II and $19 \%$ for stage III. The overall prognosis was poor.

The most widely used chemotherapy is the Etoposide/ Cisplatin (EP) where treatment has a median survival of 8-10 months for patients with extensive disease and 17-20 months for patients with limited disease [8].

The concurrent radiotherapy with chemotherapy is used as optimal treatment for limited SCLC [9].

Chemotherapy and radiation therapy were performed on the tumor after complete resection, and the relationship does not cause death in 19 patients with autopsy, in 13 patients small-cell lung cancer metastases have been cured [10]. The prognosis of SCLC is poor generally, because micrometastases occur and surgical resection is not possible. There is frequently occurring insidious transition $[10,11]$.

Nine months later PR was observed (Figure 4); patient is free from symptoms.

Another case to present is a male patient 65 years old, registered in January 2010, diagnosed by SCLC (Figure 3).

Study of chemo- and radiation therapies [12] for 28 patients died of causes other than lung cancer has been reported, and $47 \%$ was clinically cured. The autopsy study [13] of patients who died from causes other than tumors found that residual cancer cells in the area of lung cancer and mediastinal lymph node regions are $64 \%$.

The prognostic index was constructed for SCLC in Severance Hospital, Korea; retrospective evaluation of 295 patients revealed 131 with limited and 164 with extended disease. The median survival was 20.4 months for limited and 7.7 months for extended disease [14]. A prognostic index was constructed to create four classifications of SCLC considering the variables of the extension of the disease, the performance status, the CYFRA21-1, and tumor marker.

Heat therapy could be a feasible option to treat SCLC. The classical locoregional heat treatment (conventional oncological hyperthermia) has a localized area selection $[15,16]$. This boosts the chemoefficacy [17-22] and also increases the effectiveness of radiation therapy $[23,24]$.

Some successful clinical trials had shown the feasibility of the hyperthermia method for lung cancer. Most of these are applied for non-small-cell lung cancer (NSCLC), combined with radiotherapy, having $14 \div 70 \mathrm{~Gy}$ dose in the given session. The measured response rate (RR) was surprisingly high $\mathrm{RR}=75 \%(n=12[25])$ and $\mathrm{RR}=100 \%(n=13[26])$. Others had a comparison to a control arm (not randomized), growing the RR from $\mathrm{RR}=70 \%(n=30)$ and $\mathrm{RR}=53.8 \%$ $(n=13)$ to $\mathrm{RR}=94.7 \%(n=19$ [27] $)$ and $\mathrm{RR}=76.9 \%$ ( $n=13,[28]$ ), respectively. The second year survival also increased remarkably from $15 \%$ and $15.4 \%$ to $35 \%$ and $44.4 \%$, respectively. (The first year survival was measured as well, increasing from $30 \%$ to $55 \%$ [27].)
The chemothermotherapy combination was also investigated for NSCLC with success. In preclinical trials the Cisplatin was shown to be effective [29], so the clinical studies were concentrating on this drug combination. Special case report has shown the feasibility [30] and the median survival gain (from $15(n=20)$ to $25(n=32)$ months) [31]. The median survival was measured in another study [32], as 19.2 months, the $\mathrm{RR}=73 \%$ and the 1 -year survival is $75 \%$. The 5 -year median survival was measured in another study [33], showing rather high numbers $(24.5 \%, n=30)$.

However, problem arises by the classical hyperthermia. The cancer tissue is more active than the surrounding normal tissue; its cell proliferation and metabolism require a lot of energy. When temperature tries to equalize in the surrounding, it grows around the tumor. In consequence the surrounding blood vessels expand, the blood flow increases and delivers extra nutrition for tumor accelerating its stable proliferation. In this case, the temperature rise of the cancerous tissue will have more metabolic and proliferation activity. Furthermore, hyperthermia affects the intracellular heat-shock proteins (HSP), developing thermotolerance of the cells [34].

The extracellular matrix surrounding the tumor is overburdened by ionic metabolites and final metabolic products, which changes their electric properties [35, 36]. This is used by oncothermia that selects the tumorous region and absorbs the energy selectively on the malignant cells. The temperature rises only very locally on the malignant cells does not rise all over the large volume, and does not affect the surrounding normal tissue. In consequence no vasodilatation occurs, no extra proliferation is supported by the blood vessels, the absorbed energy concentrates on the job: to destroy the tumor only [37]. The method works by impedance-tuned, capacitive-coupled radiofrequency, with modulated $13.56 \mathrm{MHz}$.

One of the most advanced hyperthermia modalities devoted to oncology is oncothermia [37]. The actions are widely affecting the targeted malignant cells: passing through the malignant cell membrane $1500 \mathrm{nW} / \mu \mathrm{m}^{2}$ heat flow, while the normal tissue membranes have only $20 \mathrm{nW} / \mu \mathrm{m}^{2}$. Oncothermia treatment induces $\mathrm{Na}^{+}$influx current $150 \mathrm{pA} / \mu \mathrm{m}^{2}$ while normal $\mathrm{Na}^{+}$efflux is $12 \mathrm{pA} / \mu \mathrm{m}^{2}$ [38]. $\mathrm{Na}^{+}$moves into the malignant cell, the water is also pumped in by electroosmotic way, increasing the pressure within the cell. By these actions the cell membrane is destroyed and will destroy the cancerous tissue [39]. For these reasons we expect the effect on the disseminated SCLC lesions with combination of chemotherapy and radiation therapy. We supposed improved survival rates, when appropriate amount of energy, proper temperature, and well-chosen doses are used in the study [37].

In the preliminary reports [40-42] the feasibility of oncothermia application was demonstrated on NSCLC, and some preliminary case reports and statistical summaries on SCLC were presented in local conferences too [43, 44]. Systematic study of oncothermia applications for SCLC is still missing. Our present study tries to provide more details in this important field of oncology. 
TABle 1: Patient's profile.

\begin{tabular}{lccccccc}
\hline \multirow{2}{*}{ Age } & \multicolumn{4}{c}{ Chemotherapy alone } & \multicolumn{4}{c}{ Chemotherapy + oncothermia } \\
& M & F & Total & M & F & Total & Total \\
\hline $51-60$ & 2 & - & $\mathbf{2}$ & $\mathbf{5}$ & 1 & $\mathbf{6}$ & $\mathbf{8}$ \\
$61-70$ & 4 & - & $\mathbf{4}$ & $\mathbf{8}$ & 2 & $\mathbf{1 0}$ & $\mathbf{1 4}$ \\
$71-80$ & 1 & - & $\mathbf{1}$ & $\mathbf{6}$ & 1 & - & $\mathbf{8}$ \\
$81-90$ & - & 1 & $\mathbf{1}$ & - & - & $\mathbf{2 3}$ & $\mathbf{1}$ \\
\hline & $\mathbf{7}$ & $\mathbf{1}$ & $\mathbf{8}$ & $\mathbf{1 9}$ & $\mathbf{4}$ & $\mathbf{3 1}$ \\
\hline
\end{tabular}

\section{Materials and Methods}

A prospective, double arm, monocentric study for SCLC was performed. The small-cell lung cancer cases were treated in a combination of chemotherapy and radiation therapy, with complementary oncothermia in our study. It is considered that the applied complex protocol completed by oncothermia maximizes the effectiveness of chemotherapy and may improve the survival rate. We treated 31 patients in duration of 6 years, from April 2006 to March 2012.

7 out of 8 cases in control arm who underwent only chemotherapy were men, and in one case was a woman. The youngest was 54 years old and the oldest was 84 years old. The active arm, the combination of chemotherapy and oncothermia treatment, had 23 patients, 19 males and four females. The youngest was 54 years old; the oldest were 79 years old (see Table 1). There was no significant difference between these two groups (Fisher's exact test: $>0.9999$; $t$-test: $P$ value $\geq 0.8665)$. The real end-point of the study was the survival time.

All patients had proven SCLC and received chemotherapy. 23 patients received oncothermia in combination with chemotherapy. Oncothermia was provided with EHY-2000 device (Oncotherm GmbH, Germany).

Anticancer drug in first line was Irinotecan $\left(60 \mathrm{mg} / \mathrm{m}^{2}\right)$ and Cisplatin $\left(60 \mathrm{mg} / \mathrm{m}^{2}\right)$ three times after chest CT was taken. When the progression of tumor or metastases were detected we replaced the chemotherapy regime by Etoposide $\left(110 \mathrm{mg} / \mathrm{m}^{2}\right)$ and Cisplatin $\left(70 \mathrm{mg} / \mathrm{m}^{2}\right)$ in second line.

Oncothermia was performed from the first anticancer drug treatment period up to 150 Watt, $1,490.5 \mathrm{~kJ}$ energy by 60 minutes, every second day, with rise in temperature to $38.5^{\circ} \mathrm{C}-42.5^{\circ} \mathrm{C}$. In this study we used electrode $30 \mathrm{~cm}$ diameter applied for thorax. Other technical details are shown elsewhere [37, 45].

\section{Characteristic Cases}

A male patient aged 67 who had visited our Department with chief complaints of slight fever and sputum in August 2008 was hospitalized for a thorough examination and then diagnosed as a case of limited small cell lung cancer. For treatment, Irinotecan $\left(60 \mathrm{mg} / \mathrm{m}^{2}\right)$ and Cisplatin $\left(60 \mathrm{mg} / \mathrm{m}^{2}\right)$ were administered 12 times, and, at the same time, oncothermia was given 24 times ( 2 cycles) totally, 2 times per week. Then, chest PA and chest CT found that he was in complete remission from small cell lung cancer. So, treatments of chemotherapy and oncothermia were stopped from October 2009, and then he was in outpatient followup on a regular basis. On October 25th, 2010, PET CT showed a normal finding. In April 2011 he was treated by chemotherapy in the Department of Urology, in our hospital, for prostatomegaly. Because PSA was increased to 4.96 in June 2011, he got a prostate tissue biopsy and was diagnosed as a case of adenocarcinoma. Finally he was treated by the prostate cancer resection using the Da Vinci robot at July 2011. Chest CT in July 2011 found mediastinal lymphadenopathy, and, after mediastinoscopy, he was diagnosed as a case of metastatic small cell lung cancer. For chemotherapy, Etoposide $\left(110 \mathrm{mg} / \mathrm{m}^{2}\right)$ and Cisplatin $\left(70 \mathrm{mg} / \mathrm{m}^{2}\right)$ were 12 times administered in replacement, and another one-cycle treatment of oncothermia was given. In December 2011 and February and April 2012, follow-up chest CT found the patient was in complete remission. During outpatient followups in September 2012, chest CT found multiple nodes in the left upper and lower lobes on possible suspicion of metastasis. Under the patient's personal circumstances including general weakness, chemotherapy and oncothermia were stopped, and he is now observed in outpatient followup for more than 3 years [6].

Three months later, the checkup had shown good partial remission (PR) on the lesion (Figure 2); patient is free from symptoms.

Our case to present is a 67-year-old male, registered with symptoms of cough, low-grade fever in August 2009. The diagnosis was SCLC (Figure 1).

Eleven months later we reached complete remission (CR) (Figure 4).

He was followed-up on OPD until up to now. More than 1 year after he stopped chemotherapy and oncothermia he is in good general condition.

\section{Study Results}

Chemotherapy alone (without oncothermia) was applied for eight cases. The survival time ranged from 2 months up to 29 months. At the combination of chemotherapy and oncothermia, the survival time was from 2 months up to 36 months.

The treatment for only 1 patient was terminated. It was within 1 month after the diagnosis and treatment with 


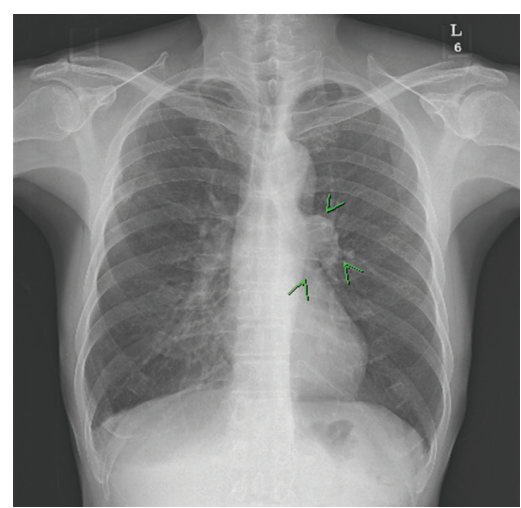

(a)

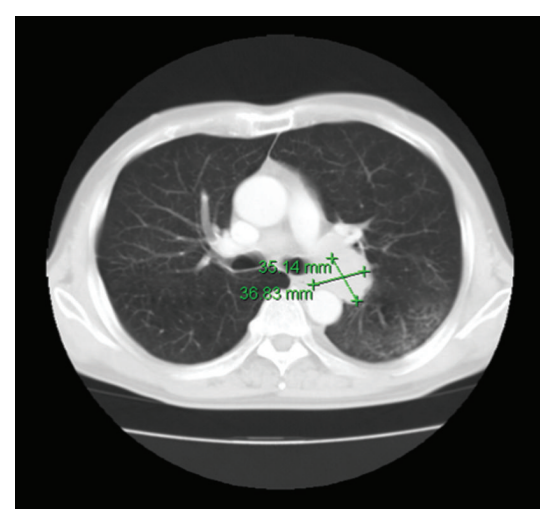

(b)

FIgURE 1: (a) Chest X-ray: in the left hilar lung tumors are found. (b) Chest CT: left hilar lung tumor approved (21 July 2009$).$

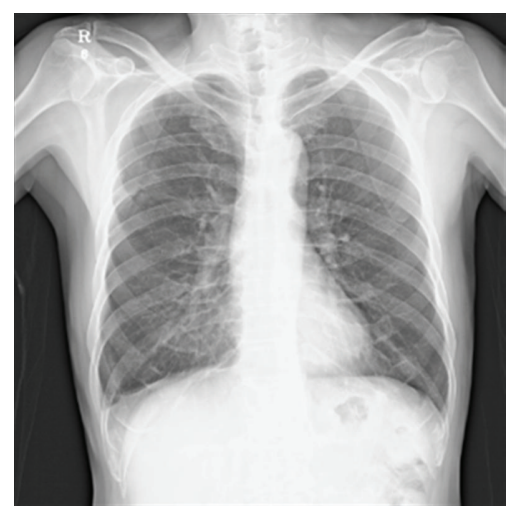

(a)

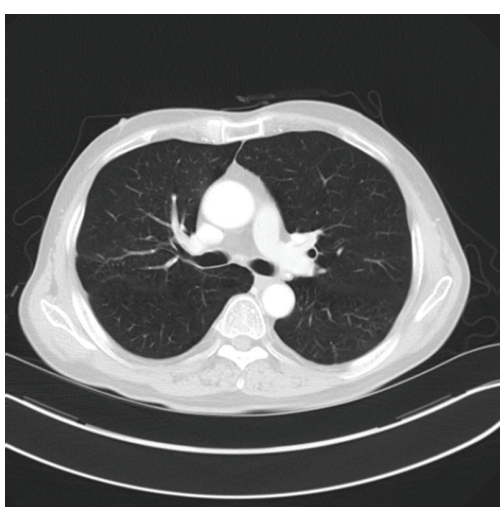

(b)

FIGURE 2: (a) Chest X-ray: PR after chemotherapy and oncothermia treatment of lung (29 April 2010), (b) chest CT: approved the PR (30th April 2010).

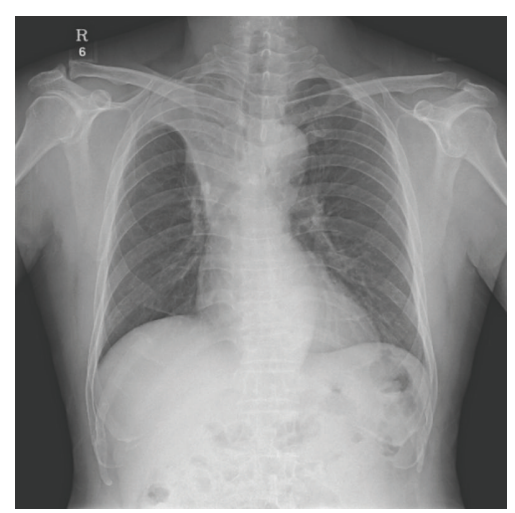

(a)

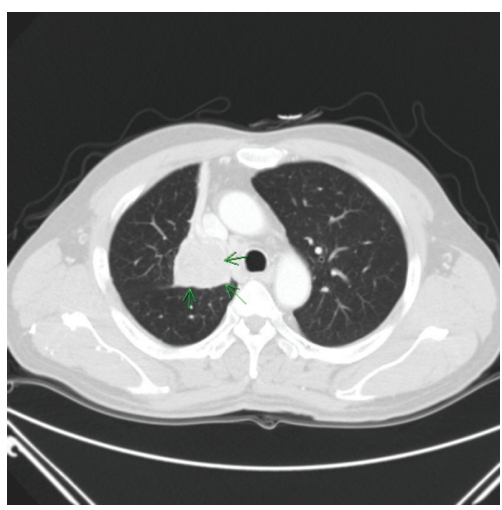

(b)

FIGURE 3: (a) Chest X-ray: the right upper lobe bronchus obstruction due to cancer as atelectasis is observed (6th January 2010). (b) Chest CT: right upper lobe bronchus and bronchial cancer is proven in the right upper lobe atelectasis (7th January 2010).

chemotherapy only. All other 31 patients underwent chemotherapy and 23 had combined treatment with oncothermia.

(1) Among 23 cases, one case died within one month after the date of diagnosis, who had been treated by chemotherapy only. Cases who have survived more than 3 years were 3 , all of whom have been treated by the combined use of chemotherapy and oncothermia.

(2) Out of 31 cases, 14 cases died during the treatment: (i) 7 cases with chemotherapy only, including one long survival case of 28 months, and (ii) 7 cases treated by 
TABLE 2: Comparison of the arms with chemotherapy without and with oncothermia in parallel.

\begin{tabular}{lccccc}
\hline & \multicolumn{4}{c}{ Summary of the number of censored and uncensored values } \\
Stratum & Group 1 & Total & Failed & Censored & Percent censored \\
\hline 1 & Chemotherapy & 8 & 7 & 1 & 12.50 \\
2 & Oncothermia in parallel & 23 & 12 & 11 & 47.83 \\
\hline Total & & 31 & 19 & 12 & 38.71 \\
\hline
\end{tabular}

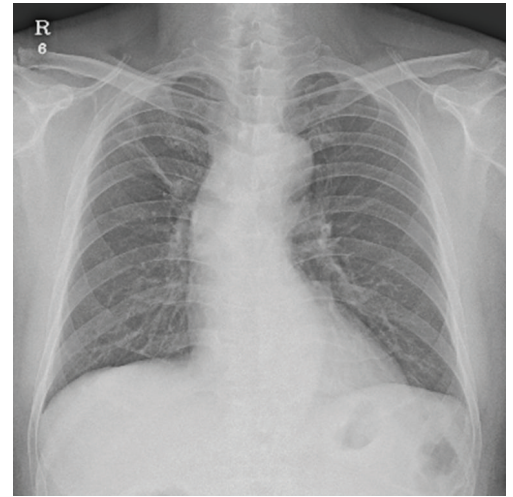

(a)

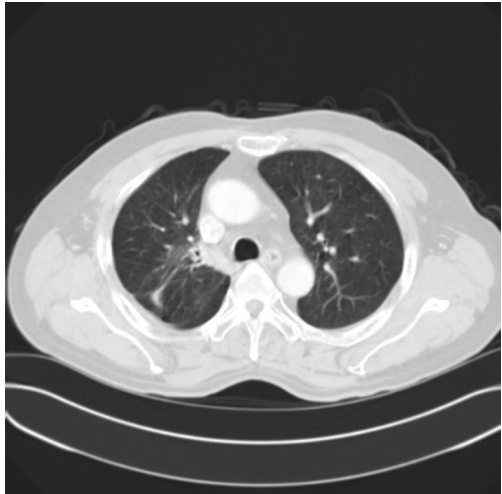

(b)

Figure 4: (a) Chest X-ray: after chemotherapy and oncothermia treatment of the right upper lobe atelectasis was not observed. (b) Chest CT: right upper lobe bronchus, bronchial cancer disappeared (23 November 2010).

the combined use of chemotherapy and oncothermia, including one long survival case of 26 months.

(3) Out of 31 cases, 16 cases are alive up to the present: 4 cases with chemotherapy only, including one long survival case of 28.7 months, and (ii) 11 cases treated by the combined use of chemotherapy and oncothermia, including three long survival cases of more than 3 years.

(4) The combined use of chemotherapy and oncothermia has significantly enhanced the survival rate in comparison with the use of chemotherapy only (log-rank test: $P$ value $=0.0200$ ).

Survival analysis Kaplan-Meier curve survival distribution (Figure 5) shows significant difference between the arms of chemotherapy with and without oncothermia. The logrank test to compare survival distributions between the two groups had hazard ratio and $95 \%$ confidence interval using Cox proportional hazard regression showing $P=0.02$. The summary is shown on Table 2 .

\section{Conclusion}

(1) In the cases of small cell lung cancer, we obtained a better treatment efficacy than the treatment of chemotherapy only, by the combined use of chemotherapy and oncothermia (one hour per each time, 2 times per week, and more than 12 times (one cycle)). Based on this, our thought is that the treatment of oncothermia, 3 times per week and more than 3 cycles, can create a good treatment efficacy.

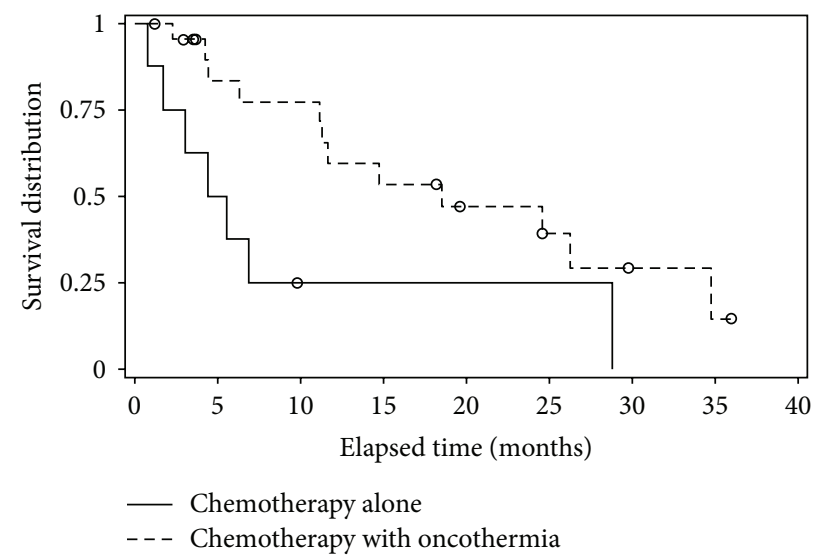

Figure 5: Kaplan-Meier survival curve: $\Rightarrow$ log-rank test, $P$ value $=0.0200$

(2) Small cell lung cancer can primarily be covered by chemotherapy (and radiotherapy sometimes), but tolerance against the anticancer agent is created frequently, and then the return of disease or metastasis takes place very often, which indicates a poor prognosis. Our thought is that the combined use of oncothermia can enhance the treatment efficacy of chemotherapy, thus getting a higher rate of survival against small cell lung cancer.

(3) But we have some limitations of not so many cases with chemotherapy and oncothermia and short periods of followup. We consider that more cases and 
longer periods of follow-up are required for a good verification.

(4) Several matters including the most suitable size of energy, time of administration, and the number of administrations should be under subsequent studies.

(5) Complementary oncothermia treatment enhances the effect of anticancer drugs to destroy the cancer cells furthermore improves the survival of patients with SCLC. However, the follow-up period was short in this study, and so a long-term follow-up is desired in the future.

The actual dose is the amount of absorbed energy, which is calculated by the power multiplied by the appropriate time of administration. The number of sessions for optimal results has to be investigated in the future.

Complementary to chemotherapy of SCLC, hyperthermia was applied twice a week, one hour duration in a session, and at least 12 times applied in 1 cycle. Results show promising improvement of the survival compared to chemotherapy alone.

Recurrence or metastasis of SLCL is rather frequent after conventional chemotherapy, and in some cases after radiotherapy, the prognosis is poor in these cases.

\section{References}

[1] T. K. Owonikoko, C. C. Ragin, C. P. Belani et al., "Lung cancer in elderly patients: an analysis of the surveillance, epidemiology, and end results database," Journal of Clinical Oncology, vol. 25, no. 35, pp. 5570-5577, 2007.

[2] M. Sørensen, M. Pijls-Johannesma, and E. Felip, "Small-cell lung cancer: ESMO clinical practice guidelines for diagnosis, treatment and follow-up," Annals of Oncology, vol. 21, supplement 5, pp. v120-v125, 2010.

[3] M. Pijls-Johannesma, D. de Ruysscher, J. Vansteenkiste, A. Kester, I. Rutten, and P. Lambin, “Timing of chest radiotherapy in patients with limited stage small cell lung cancer: a systematic review and meta-analysis of randomised controlled trials," Cancer Treatment Reviews, vol. 33, no. 5, pp. 461-473, 2007.

[4] D. J. Samson, J. Seidenfeld, G. R. Simon et al., "Evidence for management of small cell lung cancer: ACCP evidence-based clinical practice guidelines (2nd edition)," Chest, vol. 132, no. 3 , supplement, pp. 314S-323S, 2007.

[5] C. J. Williams, I. McMillan, R. Lea et al., "Surgery after initial chemotherapy for localized small-cell carcinoma of the lung," Journal of Clinical Oncology, vol. 5, no. 10, pp. 1579-1588, 1987.

[6] A. T. Turrisi III, K. Kim, R. Blum et al., "Twice-daily compared with once-daily thoracic radiotherapy in limited small-cell lung cancer treated concurrently with cisplatin and etoposide," The New England Journal of Medicine, vol. 340, no. 4, pp. 265-271, 1999.

[7] F. A. Shepherd, R. J. Ginsberg, R. Feld, W. K. Evans, and E. Johansen, "Surgical treatment for limited small-cell lung cancer: the University of Toronto Lung Oncology Group experience," Journal of Thoracic and Cardiovascular Surgery, vol. 101, no. 3, pp. 385-393, 1991.

[8] J. S. Lee, J. Han, S. Yu et al., “The progress of small cell lung cancer management using irinotecan plus cisplatin chemotherapy,"
Journal of Clinical Oncology, vol. 25, no. 18, supplement, 2007, ASCO Annual Meeting Proceedings, no. 7721.

[9] K. Park, J.-M. Sun, S.-W. Kim et al., "Phase III trial of concurrent thoracic radiotherapy (TRT) with either the first cycle or the third cycle of cisplatin and etoposide chemotherapy to determine the optimal timing of TRT for limited-disease small cell lung cancer," Journal of Clinical Oncology, vol. 30, no. 15, supplement, 2012, ASCO Annual Meeting Proceedings, no. 7004.

[10] M. J. Matthews, S. Kanhouwa, J. Pickren, and D. Robinette, "Frequency of residual and metastatic tumor in patients undergoing curative surgical resection for lung cancer," Cancer Chemotherapy Reports, vol. 4, no. 2, article 63, 1973.

[11] C. F. Mountain, "Clinical biology of small cell carcinoma: relationship to surgical therapy," Seminars in Oncology, vol. 5, no. 3, pp. 272-279, 1978.

[12] A. S. Lichter, P. A. Bunn Jr., D. C. Ihde et al., "The role of radiation therapy in the treatment of small cell lung cancer," Cancer, vol. 55, no. 9, supplement, pp. 2163-2175, 1985.

[13] J. A. Elliott, K. Osterlind, F. R. Hirsch, and H. H. Hansen, "Metastatic patterns in small-cell lung cancer: correlation of autopsy findings with clinical parameters in 537 patients," Journal of Clinical Oncology, vol. 5, no. 2, pp. 246-254, 1987.

[14] S. Hong, B. C. Cho, H. J. Choi et al., "Prognostic factors in small cell lung cancer: a new prognostic index in Korean patients," Oncology, vol. 79, no. 3-4, pp. 293-300, 2010.

[15] M. H. Seegenschmiedt, P. Fessenden, and C. C. Vemon, Eds., Thermo-Radiotherapyand Thermo-Chemotherapy, Vol. 1: Biology, Physiology and Physics, Springer, Berlin, Germany, 1996.

[16] M. H. Seegenschmiedt, P. Fessenden, and C. C. Vemon, Eds., Thermo-Radiotherapy and Thermo-Chemotherapy, Vol. 2. Clinical Applications, Springer, Berlin, Germany, 1996.

[17] M. Urano and E. Douple, Eds., Hyperthermia and Oncology. Vol. 1. Thermal Effects on Cells and Tissues, VSP, Utrecht, The Netherlands, 1998.

[18] M. Urano and E. Douple, Eds., Hyperthermia and Oncology. Vol. 2. Biology of Thermal Potentiation of Radiotherapy, VSP, Utrecht, The Netherlands, 1989.

[19] M. Urano and E. Douple, Eds., Hyperthermia and Oncology. Vol. 3. Interstitial Hyperthermia: Physics, Biology and Clinical Aspects, VSP, Utrecht, The Netherlands, 1992.

[20] M. Urano and E. Douple, Eds., Hyperthermia and Oncology. Vol. 4. Chemo-Potentiation by Hyperthermia, VSP, Utrecht, The Netherlands, 1994.

[21] C. E. Lindholm, Hyperthermia and radiotherapy [Ph.D. thesis], Lund University, Malmo, Sweden, 1992.

[22] G. D. Gonzales, "Thermo-radiotherapy for tumors of the lower gastro-instenstinal tranc," in Thermo-Radiotherapy and Thermo-Chemotherapy Biology and Physics, M. H. Seegenschmiedt, P. Fessecden, and C. C. Vernon, Eds., Springer, Berlin, Germany, 1996.

[23] W. C. Dewey, L. E. Hopwood, S. A. Sapareto, and L. E. Gerweck, "Cellular responses to combinations of hyperthermia and radiation," Radiology, vol. 123, no. 2, pp. 463-474, 1977.

[24] C. Muller, "Therapeutische Erfahrungen an 100 mit kombination von Rontgenstrahlen un hochfrequenz, resp. Diathermie behandeleten bosartigen Neubildungen," Münchener Medizinische Wochenschrift, vol. 28, pp. 1546-1549, 1912.

[25] M. Hiraoka, S.-I. Masunaga, Y. Nishimura et al., "Regional hyperthermia combined with radiotherapy in the treatment of lung cancers," International Journal of Radiation Oncology, Biology, Physics, vol. 22, no. 5, pp. 1009-1014, 1992. 
[26] H. Imada, S. Nomoto, A. Tomimatsu et al., "Local control of nonsmall cell lung cancer by radiotherapy combined with high-power hyperthermia using $8 \mathrm{MHz}$ RF capacitive heating device," Japanese Journal of Hyperthermic Oncology, vol. 15, pp. 19-24, 1999.

[27] K. Karasawa, N. Muta, K. Nakagawa et al., “Thermoradiotherapy in the treatment of locally advanced nonsmall cell lung cancer," International Journal of Radiation Oncology, Biology, Physics, vol. 30, no. 5, pp. 1171-1177, 1994.

[28] H. Sakurai, K. Hayakawa, N. Mitsuhashi et al., "Effect of hyperthermia combined with external radiation therapy in primary non-small cell lung cancer with direct bony invasion," International Journal of Hyperthermia, vol. 18, no. 5, pp. 472-483, 2002.

[29] J. V. E. Hettinga, W. Lemstra, C. Meijer et al., "Hyperthermic potentiation of cisplatin toxicity in a human small cell lung carcinoma cell line and a cisplatin resistant subline," International Journal of Hyperthermia, vol. 10, no. 6, pp. 795-805, 1994.

[30] M. Higashiyama, O. Doi, K. Kodama, and H. Yokouchi, "Intrathoracic chemothermotherapy following panpleuropneumonectomy for pleural dissemination of invasive thymoma," Chest, vol. 105, no. 6, pp. 1884-1885, 1994.

[31] O. Doi, K. Kodama, M. Higashiyama, K. Kuriyama, and R. Tateishi, "Postoperative chemothermotherapy fo locally advanced lung cancer with carcinomatous pleuritis," in Cancer Treatment by Hyperthermia, Radiation and Drugs, T. Matsuda, Ed., chapter 31, pp. 338-352, Taylor Francis, London, UK, 1993.

[32] H. Yang, G. Jiang, X. Fu, and J. Liao, "Radiotherapy and hyperthermia for NSCLC," Journal of Clinical Oncology, vol. 23, no. 16, supplement, 2005, ASCO Annual Meeting Proceedings, no. 7289 .

[33] K. Kodama, O. Doi, M. Higashiyama, H. Yokouchi, and M. Tatsuta, "Long-term results of postoperative intrathoracic chemothermotherapy for lung cancer with pleural dissemination," Cancer, vol. 72, no. 2, pp. 426-431, 1993.

[34] M. Xu, W. D. Wright, R. Higashikubo, and J. L. Roti, "Chronic thermotolerance with continued cell proliferation," International Journal of Hyperthermia, vol. 12, no. 5, pp. 645-660, 1996.

[35] S. R. Smith, K. R. Foster, and G. L. Wolf, "Dielectric properties of VX-2 carcinoma versus normal liver tissue," IEEE Transactions on Biomedical Engineering, vol. 33, no. 5, pp. 522-524, 1986.

[36] L. A. Dissado, J. M. Alison, R. M. Hill, D. A. McRae, and M. A. Esrick, "Dynamic scaling in the dielectric response of excised EMT-6 tumours undergoing hyperthermia," Physics in Medicine and Biology, vol. 40, no. 6, pp. 1067-1084, 1995.

[37] A. Szasz, N. Szasz, and O. Szasz, Oncothermia-Principles and Practices, Springer Scientific, Heidelberg, Germany, 2010.

[38] A. Szasz, G. Vincze, O. Szasz, and N. Szasz, "An energy analysis of extracellular hyperthermia," Electromagnetic Biology and Medicine, vol. 22, no. 2-3, pp. 103-115, 2003.

[39] T. Galeotti, S. Borrello, G. Minotti, and L. Masotti, "Membrane alterations in cancer cells: the role of oxy radicals," in Membrane Pathology, G. Bianchi, E. Carafoli, and A. Scarpa, Eds., vol. 488, pp. 468-480, Annals of the New York Academy of Sciences, 1986.

[40] A. Dani, A. Varkonyi, M. Osvath, and A. Szasz, "Treatment of non-small-lunk-cancer by electro-hyperthermia," Strahlentherapie und Onkologie, vol. 180, p. 20, 2004.

[41] A. Dani, A. Varkonyi, I. Nyiro, and M. Osvath, Clinical Experience of Electro-Hyperthermia for Advanced Lung-Tumors, ESHO, Munich, Germany, 2003.
[42] E. D. Hager, I. H. Krautgartner, C. Popa, D. Hohmann, and H. Dziambor, "Deep hyperthermia with short waves of patients with advanced stage lung cancer, hyperthermia in clinical practice," in Proceedings of the 22nd Meeting of the International Clinical Hyperthermia Society, 1999.

[43] D. Y. Lee, S. J. Haam, H. C. Paik, B. J. Lim, T. H. Kim, and N. Y. Kim, "Complete remission of SCLC with chemotherapy and oncothermia (case report)," Oncothermia Journal, vol. 5, pp. 4351, 2012.

[44] S. M. Yoon and J. S. Lee, "Case of abscopal effect with metastatic non-small cell lung cancer," Oncothermia Journal, vol. 5, pp. 5257, 2012.

[45] A. Szasz, O. Szasz, and N. Szasz, "Physical background and technical realization of hyperthermia," in Locoregional Radiofrequency-Perfusional-and Wholebody-Hyperthermia in Cancer Treatment: New Clinical Aspects, G. F. Baronzio and E. D. Hager, Eds., chapter 3, pp. 27-59, Springer, New York, NY, USA, 2006. 

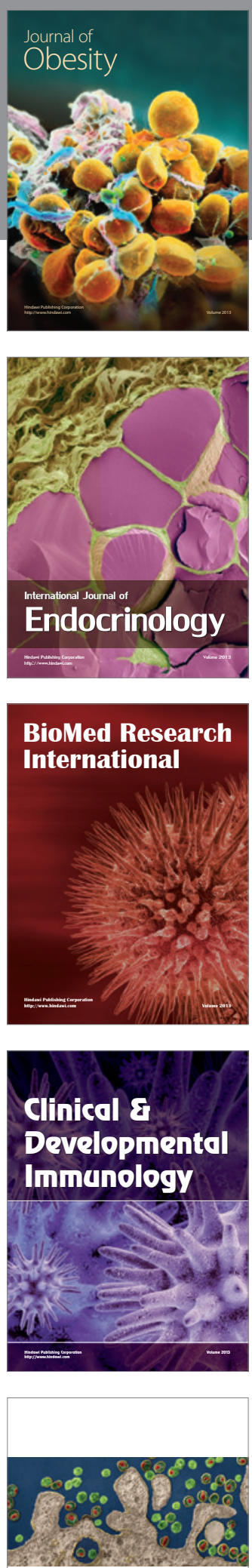

ISRN

AIDS
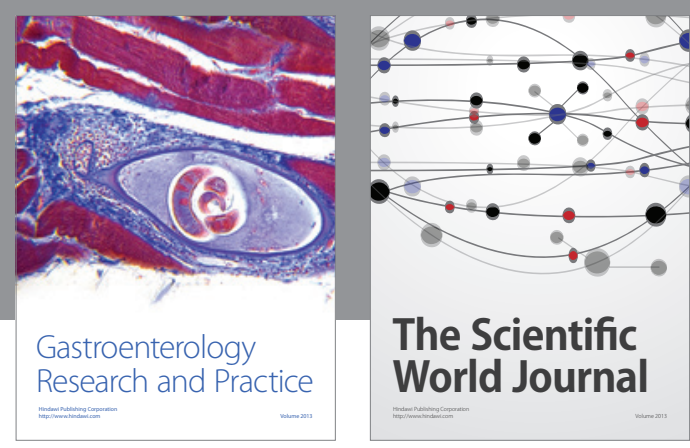

The Scientific World Journal
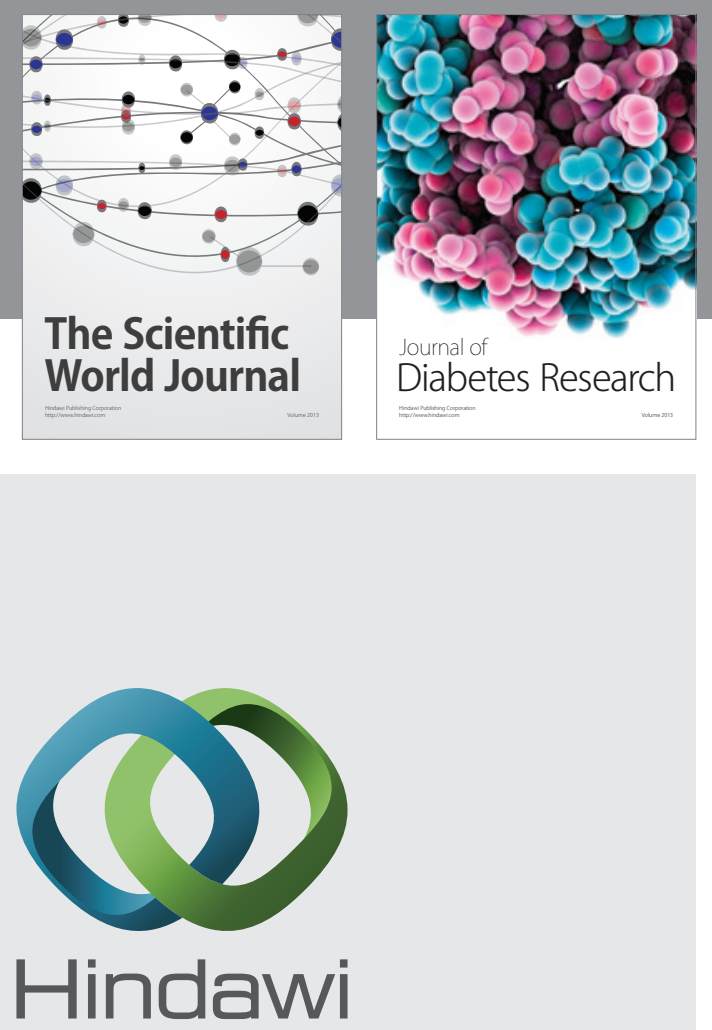

Submit your manuscripts at

http://www.hindawi.com
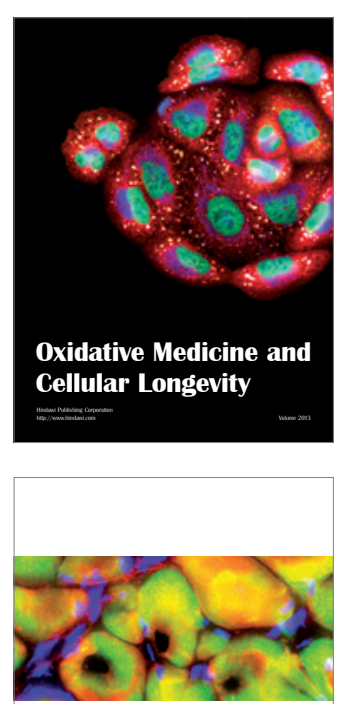

ISRN

Biomarkers
MEDIATORS

INFLAMMATION
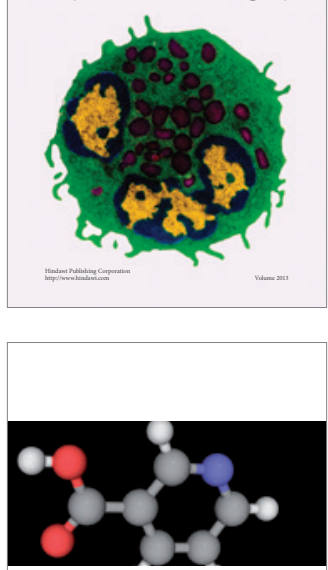

ISRN

Addiction
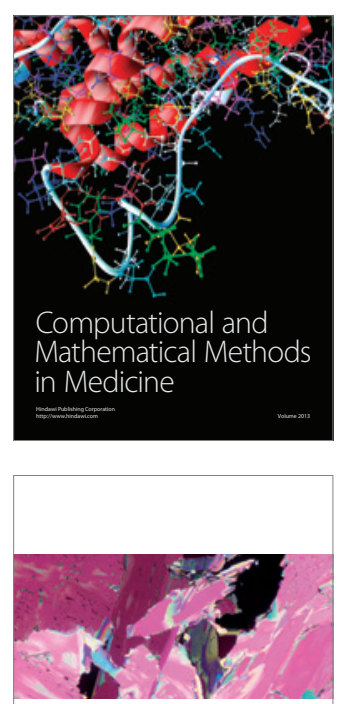

ISRN

Anesthesiology
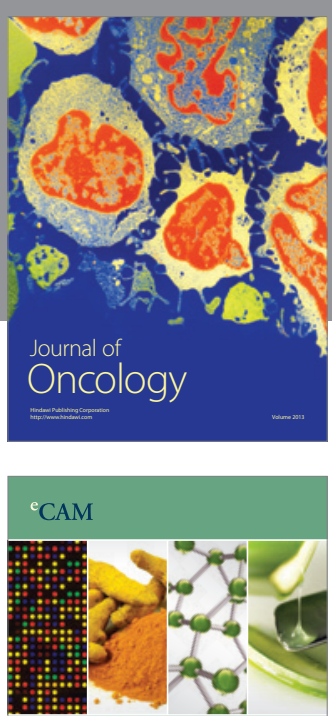

Evidence-Based

Complementary and

Alternative Medicine
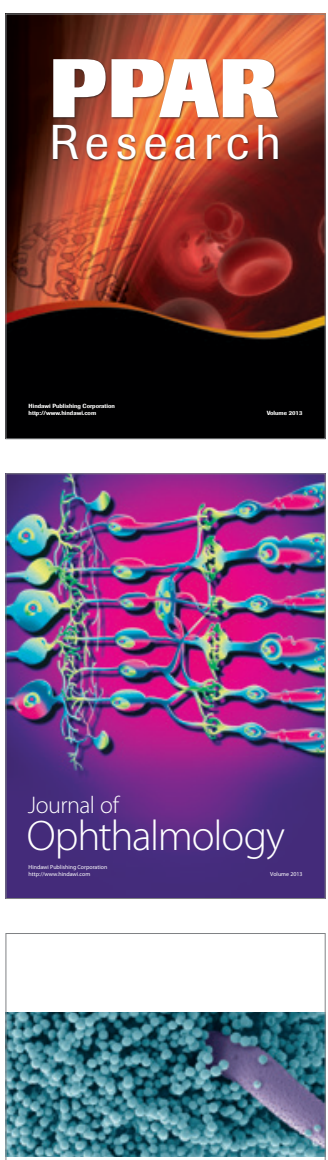

ISRN

Allergy 


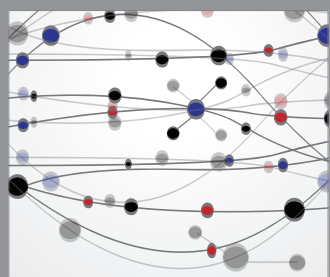

The Scientific World Journal
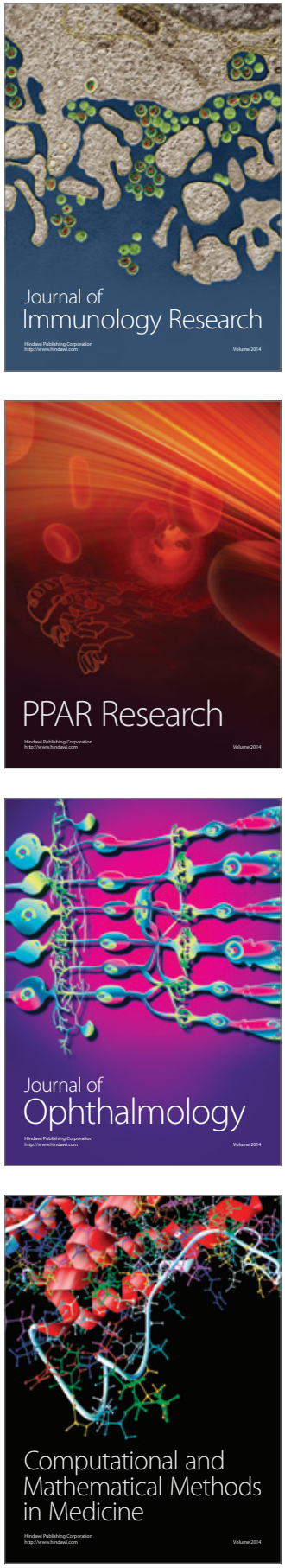

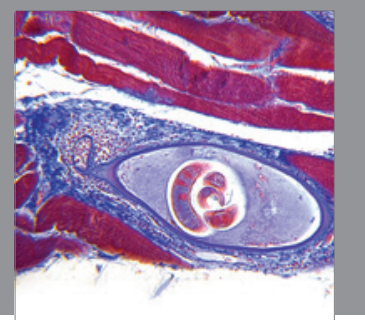

Gastroenterology

Research and Practice
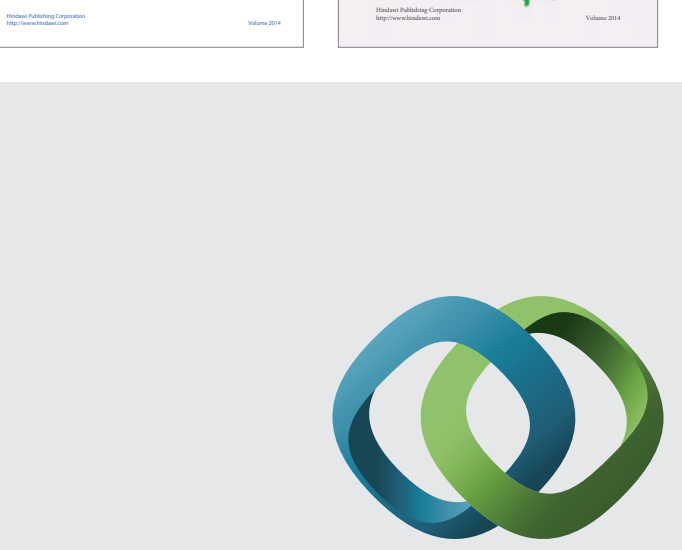

\section{Hindawi}

Submit your manuscripts at

http://www.hindawi.com
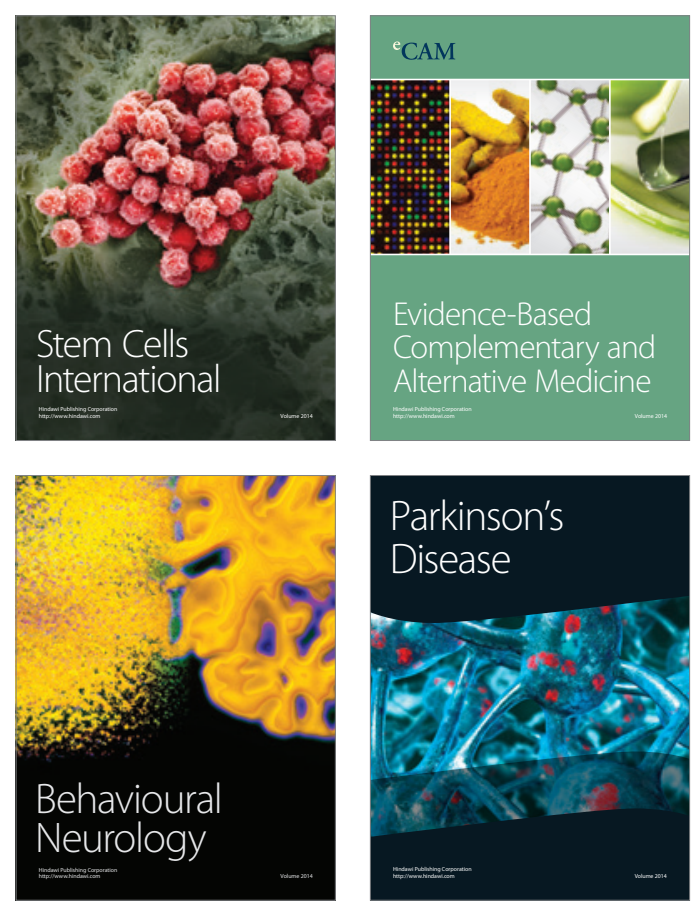

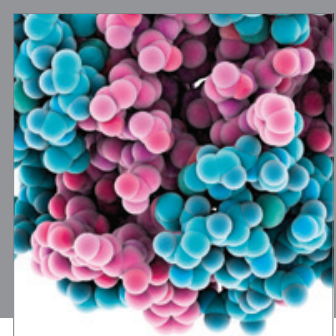

Journal of
Diabetes Research

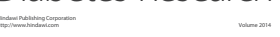

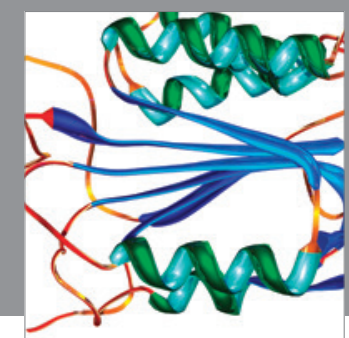

Disease Markers
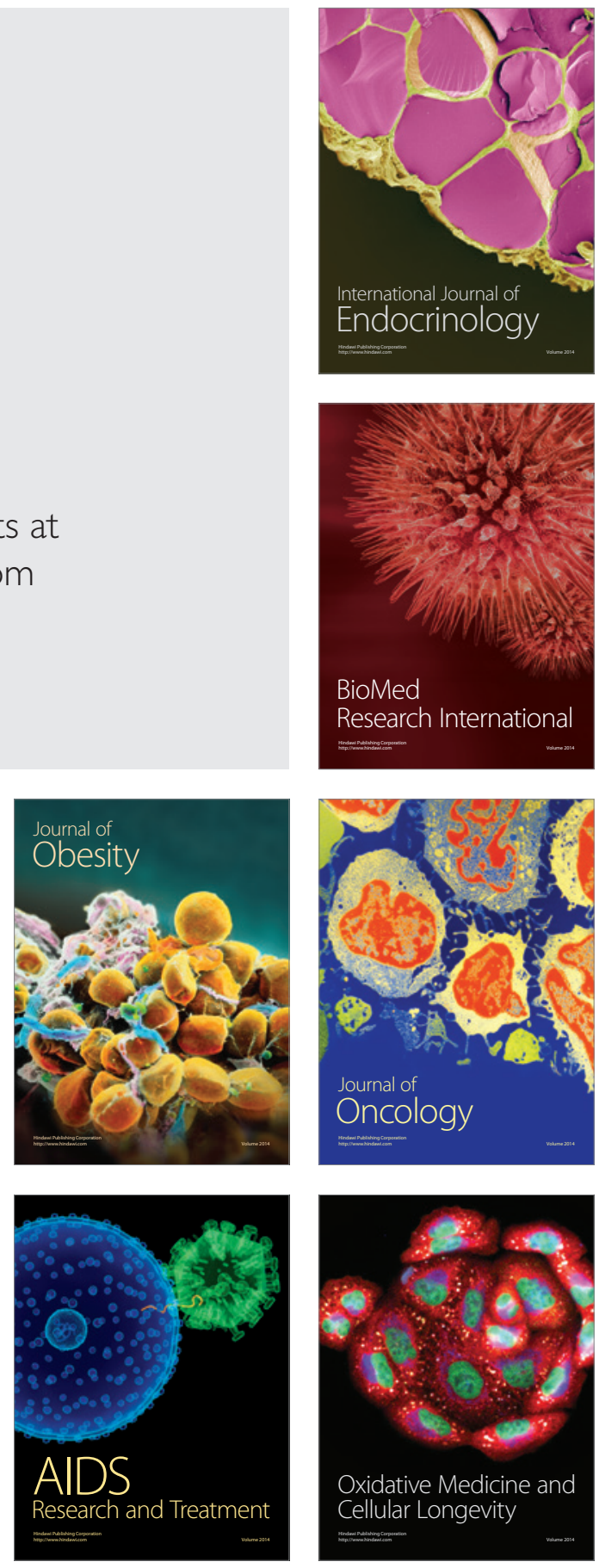